\title{
Hurleya kalamundae n.g.n.sp. (Amphipoda, Gammaridae) from subterranean waters of Western Australia
}

\author{
By Milan Straškraba ${ }^{1}$ ) \\ With plate 56 (1) - 57 (2)
}

Among Amphipods I obtained from Western Australian Museum, Perth, through the courtesy of Dr. R. W. George, a few specimens from a well at Kalamunda were recognized as representatives of a new species, related to no known genera. It represents a new genus I am naming in honour of the eminent specialist of Amphipods from Southern Hemisphere, Dr. D. E. Hurley. This is in addition to Protocrango$n y x$ fontinalis Nicholls, 1926, and is the second subterranean Amphipod known from Western Australia. Some more subterranean Amphipoda are known to occur in southeastern Australia. Although this region is zoogeographically different from Western Australia we may well expect to find additional new genera in this country.

Hurleya n. g.

Body compressed, segments of urosome free. Head with lateral lobes rounded, without eyes. Antenna 1 longer than antenna 2, accessory flagellum multiarticulated. Gnathopod 1 and 2, propodus subchelate, similar in both gnathopoda, palma with simple stout spines. Carpus short, triangular. Coxal plates lower than the corresponding segments, 1-4 deeper than the following. Basal joints of peraeopod 7 moderately enlarged. Peraepod 7 the longest. Mandibular palp differentiated. Maxilla 1 with inner plate bearing a few plumose setae, outer plate armed with seven serrate spine teeth, palp 2-jointed and bearing different armature on the left and right side. Maxilla 2, inner plate bearing some plumose setae apically, inner margin fringed with hairs. Maxillipeds with the inner and outer plates well developped; inner plate bearing 4 spine teeth, outer plate with marginal teeth, palp 4-jointed. Lower lip without inner lobes, outer lobes narrow. Uropod 3 biramous, exopod two-jointed, terminal joint rudimentary, endopod scale-like. Telson small, deeply cleft, lobes large and rounded apically.

1) Hydrobiological Laboratory, Czechoslovac Academy of Sciences, Praha. 


\section{Hurleya kalamundae n. sp.}

Material: From well, Kalamunda (twelve miles east of Perth), Western Austral. Mus. No. 404/6-1954, 3 spm.

Type: Female with oostegites, $8 \mathrm{~mm}$.

Diagnosis: Antenna long, exceeding half body length. Peduncular joints 1 and 2 subaequal, joint 3 about $2 / 3$ of the preceding ones. Flagellum about twice as long as peduncle. Accessory flagellum 5-jointed. Antenna 2 longer than half the antenna 1, peduncle longer than in antenna 1. Joints 4 and 5 subaequal in length, very feebly armed. Flagellum about as long as joints 4 and 5 combined, comprised of nine joints.

Mandibular palp with the second joint long, armed proximally by an irregular row of 9 setae. Terminal joint about half as long as the second one with a regular row of equally short setae in the proximal half and 3 long setae terminally.

Maxilla 1, inner plate with two plumose setae distally and fine setules on the outer margin. Outer plate with serrated spines, left palp with 5 stout spines and 1 seta, right palp with setae.

Maxilla 2, inner plate narrow, slightly shorter than outer and bearing 12 setae distally, one stout seta near the inner margin and a row of fine setules along the inner margin. Maxilliped, inner plate armed distally with four spine teeth and several setae distally and on the inner margin. Outer plate, inner margin with teeth, reaching about to half the second joint of palp. Palp of maxilliped long. Lower lip without inner lobes, outer lobes narrow.

Coxal plates 1-4 longer than broad, lower margins with several short and 1 longer seta. Lower hind corner of coxa 1-2 with two spinelike setae, coxa 4 not excavated behind. Gnathopod 2 larger than gnathopod 1, propodus birn-shaped, hind marginal border short, with 3-4 groups of setae. Palma rather oblique, with simple stout spines and 2-3 subpalmar setae. Carpus triangular. Peraeopods 3-7 increasing in length, 7th much longer than 6th, joints without long setae, dactyli with $3-5$ spines, claw short. Basipodid of peraeopods 5-6 moderately enlarged, in peraeopod 7 narrowing to the proximal end, lower hind corner indistinct. Oostegites broad, large.

Epimeral plates rounded, armed with a continuous row of marginal spines. Pleopods with both rami equally developped. Urosom short, not coalesced. Dorsally one lateral spine on segments 2 and 3. Uropoda 1 and 2 with the inner ramus shorter than the outer. Rami about equally long as peduncle. Uropod 3, endopod scale-like, exopod nearly twice as long as basis, armed by several groups of short spines. Terminal joint rudimentary. Telson small, cleft to $2 / 3$, lobes large and 
apically rounded. 1 strong terminal spine and $0-1$ feeble subterminal ones on each lobe.

Variability: Both other specimens available, of the total length of 5 and $4 \mathrm{~mm}$., seem not to differ in any of the characters indicated from the type, except the number of setae on different parts is lower in accordance with the juvenity of these specimens. Secondary sexual characters are not distinguishable, structure of gnathopoda and uropoda is similar. Specimens have not been dissected as to distinguish males and females. The number of joints in the accessory flagellum of antenna 1, an important generic character, is in these specimens 4 in difference to 5 in the type specimen.

Taxonomic relations: Males of Hurleya are not known, and this may well cause some difficulties. With a great degree of probability, however, we may expect they will not considerably differ from females described herewith. Schellenberg (1936) distinguished the slight development of secondary sexual characters as a regularity within the Crangonyx-section of freshwater Gammaridae, and this is the group to which our genus seems to be related. It is indicated mainly by the reduced uropod 3 and also the general shape and similarity of gnathopoda 1 and 2 . In respect to the shape of telson and uropoda, resemblances may be also found with two other genera of Australian Gammaridae, Neoniphargus sensus stricto (Straškraba, 1964) and a part of Australian Gammarus comprised of the previously described species mortoni (Thomson, 1893), antipodeus and ripensis Smith, 1909, and barringtonensis Chilton, 1916. Other characters, however, indicate the resemblance is not due to generic relations.

The almost exclusively subterranean freshwater Crangonyx-group was defined by Schellenberg (1936). Shoemaker (1942) elevated the generic group to a distinct section within the freshwater representatives of Gammaridae, opposing to the Gammarus section. He attributed this dichotomy to Schellenberg, although this is not justified. In his diagnosis of the group, Schellenberg gives a character concerning gnathopoda (metacarpus not quadratically enlarged) showing he distinguished at least another group for genera related to Niphargus. This is evident from his Pseudoniphargus paper (1939) where he discussed the attribution of this genus to "Kreis von Niphargus" or "Kreis von Crangonyx." Shoemaker used also somewhat different characters partly due to the restriction of his treatment to American representatives. The greatest value was led on the accessory flagellum of antenna 1, "rudimentary or consisting of one long and one short joint" in his Crangonyx-section. The presence of numerous notched spine teeth on gnathopod palms in all species was indicated. Ruffo 
(1956) showed Shoemaker's division was partly incorrect also for the American representatives as regarding the attribution of Metaniphargus to the Crangonyx section and of the undoubtedly closely related Weckelia to the Gammarus section. This was based on the character of accessory flagellum, due to neglect of the non-american genera. In the Western Australian Protocrangonyx they are two subequal joints in the flagellum, in North African Metacrangonyx 3 joints and this overarched the difference from Weckelia with four joints. As indicated already by Shoemaker the notched palmar spine teeth are lacking in gnathopod 1 of Metaniphargus, this is true also for gnathopod 1 of Weckelia. In Psammoniphargus, a recently described genus from Madagascar by Ruffo (1956) related to Metaniphargus and Weckelia palmar spines are simple in both gnathopoda. In Protocrangonyx the row of spine teeth is completely lacking.

Hurleya bears also simple palmar spines. The accessory flagellum is in this genus 5 jointed which prevents the inclusion to the Crangonyx group as characterized by previous authors. As indicated above, however, the absolute validity of the reduced accessory flagellum was diminished by recent findings and we may well enlarge the characteristic of the group to include Hurleya. All other characters lie within the range of the group, although these are mostly not strictly confined to it (the armature of urus, shape of telson).

The new genus shows little resemblence with the geographically nearest Protocrangonyx from the Darling Ranges. The antenna in this genus has a two-jointed accessory appendage, coxal plates are very low, propodus of gnathopoda completely different, bases of peraeopoda narrow, dactyli with single spines, pleopoda with the inner ramus reduced, uropoda 1-3 very short, telson entire. In Paracrangonyx, the New Zealand representative of the group the secondary appendage is, like Protocrangonyx biarticulate, coxae low, basis of peraeopoda narrow, dactyli with single spines, uropoda 1 and 2 short and telson entire. Propodus of gnathopoda 1 and 2 is much more similar to Hurleya, carpus, however, is rather different. Uropod 3 is longer than in Hurleya. Pleopoda are in this genus uniramous.

Summarizing the discussion on taxonomic relations of the new genus, we consider it to be an aberrant line of the Crangonyx group of Gammaridae.

\section{SUMMARY}

A new genus and species of freshwater Gammaridae (Amphipoda) from subterranean waters of Western Australia is described, Hurleya kalamundae n.g. n. sp. The genus apparently represents an aberrant line of the Crangonyx group of Gammaridae. 


\section{RÉSUMÉ}

La description d'Hurleya kalamundae n.g. n. sp. des Gammaridae (Amphipoda) souterrains de l'Australie Occidentale est donnée ci-dessous. Le genre nouveau montre quelques affinités avec le groupe de Crangonyx et il est considéré préliminairement comme représentatif d'une branche aberrante de ce groupe.

\section{REFERENCES}

Chilton, C. (1894) - The subterranean Crustacea of New Zealand, with some remarks on the fauna of caves and wells. - Trans. Linn. Soc. London (2) 16: 163-284.

Methuen, P. A. (1911) - On an Amphipod from the Transvaal. - Proc. Zool. Soc. Lond. 65: 948-957.

Nicholls, G. E. (1926) - Protocrangonyx fontinalis, a new freshwater Amphipod from Western Australia. - Journ. Roy. Soc. Western Australia 12: 71-78.

Ruffo, S. (1956) - Psammoniphargus pauliani n.g. n.sp. Nouveau gammaride des eaux interstitielles de l'île de la Réunion. - Mém. Inst. Sci. Madagascar (A) 11: 89-95.

Schellenberg, A. (1936) - Die Amphipoden-Gattungen um Crangonyx, ihre Verbreitung und ihre Arten. - Mitt. zool. Mus. Berlin 22: 31-44.

- (1939) - Verbreitung und Alter der Amphipoden-Gattung Pseudoniphargus nebst Verbreitung der Gattung Niphargus. - Zool. Anz. 127: 297-304.

Shozmaker, C. R. (1942) - Notes on some American freshwater Amphipod Crustaceans and description of a new genus and two new species. Smiths. Misc. Coll. 101, 9: 1-31.

Straškraba, M. (1964) - Perthia n.g. (Amphipoda, Gammaridae) from freshwater of Western Australia, with remarks on the genera Neoniphargus and Uroctena. - Crustaceana 7: 125-139.

\section{EXPLANATIONS OF PLATES $56(1)-57$ (2)}

Fig. 1: Hurleya kalamundae n.g. n.sp., holotype female $8 \mathrm{~mm}$., total view. Orig.

Fig. 2 : Hurleya kalamundae, holotype, mouth-parts. A maxilla 2, B maxilla 1, C maxilliped, D lower lip. Orig.

Fig. 3: Hurleya kalamundae, holotype, trunk limbs. A gnathopod 1, B gnathopod 2, C peraeopod 3, D peraeopod 5, E peraeopod 7. Orig.

Fig. 4: Hurleya kalamundae, holotype. A antenna 1, peduncle and accessory flagellum, B coxal plates 2-4 (from left to right), C uropod 3, D telson. Orig. 

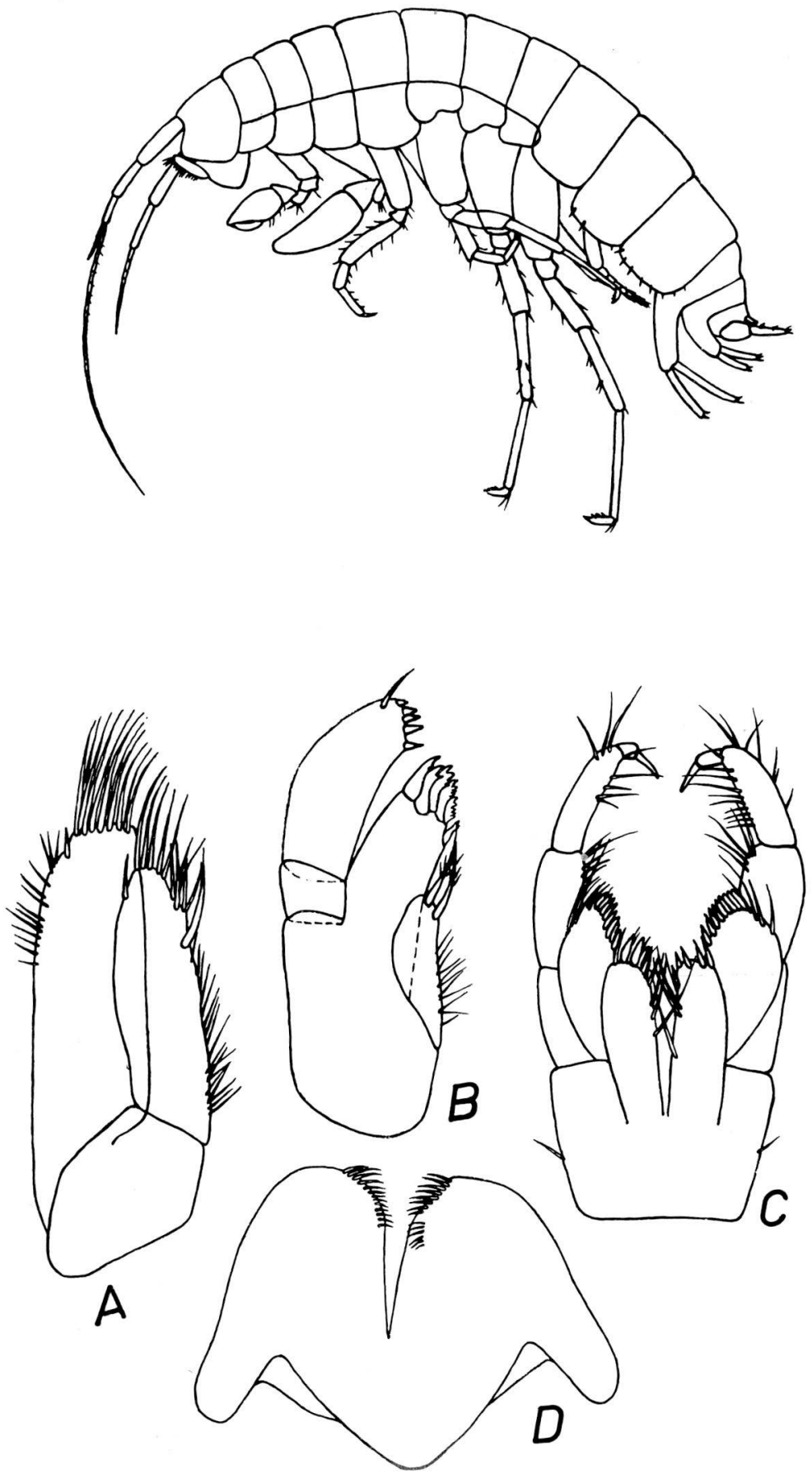

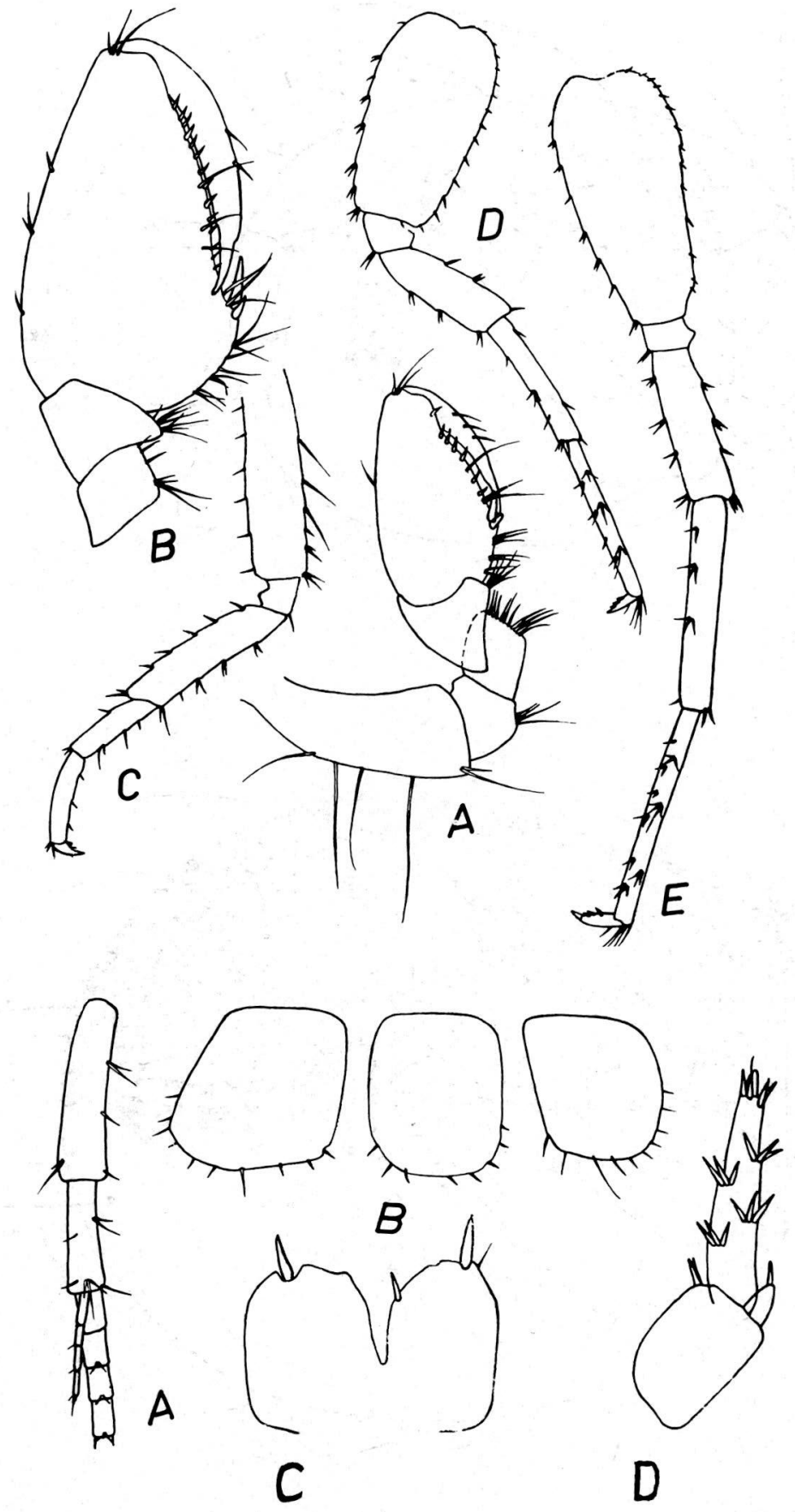